\title{
Use of the Physician Orders for Life-Sustaining Treatment Program in the Clinical Setting: A Systematic Review of the Literature
}

Susan E. Hickman PhD1,2, ${ }^{*}$, Elisabeth Keevern BSN1 and Bernard J. Hammes PhD3

1 School of Nursing, Indiana University, Indianapolis, Indiana

2 Research in Palliative and End-of-Life Communication and Training Center, Indiana University-

Purdue University, Indianapolis, Indiana

3 Department of Medical Humanities, Gundersen Medical Foundation, La Crosse, Wisconsin

*Address correspondence to: Susan E. Hickman, Indiana University School of Nursing, 1111

Middle Drive, e419, Indianapolis, IN 46220. Email: hickman@iu.edu

\begin{abstract}
The Physician Orders for Life-Sustaining Treatment (POLST) form is a palliative care tool that contains standardized, actionable medical orders. It is designed to ensure that patient treatment preferences are elicited, communicated, and honored throughout the healthcare system. A systematic review of the literature was conducted to evaluate what is currently known about the POLST program and identify directions for future research. Twenty-three research studies focused on POLST use in the clinical setting were identified. A majority of studies have been conducted all or in part in Oregon, with chart review the most frequently used methodology. Research suggests that POLST is most commonly used in older, white patients who are near the end of life. A nonphysician facilitator usually prepares the POLST form for the physician to review and sign. The orders documented on POLST reflect a wide degree of
\end{abstract}

This is the author's manuscript of the article published in final edited form as:

Hickman, S. E., Keevern, E., \& Hammes, B. J. (2015). Use of the physician orders for life-sustaining treatment program in the clinical setting: a systematic review of the literature. Journal of the American Geriatrics Society, 63(2), 341-350. http://doi.org/10.1111/igs.13248 
individualization, with only approximately one-third of patients having orders reflecting the lowest level of treatment in all POLST form sections. Clinicians have generally positive attitudes regarding use of POLST yet report a wide range of challenges. POLST alters treatment in a way that is consistent with orders. However, evidence that POLST reflects patient or surrogate treatment preferences is lacking. Research is needed to evaluate the quality of POLST decisions, explore the experiences of patients and their surrogates, develop decision-support tools, improve clinician education, and assess the effect of POLST on care outcomes through intervention and population-based studies.

Introduction

An important component of geriatric palliative care is to help patients and their surrogates make complex medical decisions and ensure that those decisions are honored.[1] The Physician Orders for Life-Sustaining Treatment (POLST) program is designed to help ensure that treatment preferences are elicited, communicated, and honored. The centerpiece of the POLST program is a standardized form that contains medical orders to convey a patient's treatment preferences. The form transfers between care settings so that it is available to help guide treatment discussions and decisions.[2] POLST is intended for patients with advanced chronic progressive disease or frailty. It has been identified by the National Quality Forum as a preferred palliative care practice[1] and by the Center to Advance Palliative Care as a preferred palliative care practice in nursing facilities.[3]

The POLST form builds upon the standard practice of writing code status orders based on cardiopulmonary resuscitation (CPR) preferences, but expands beyond CPR to address preferences for a broader range of treatments. $[2,4]$ Section $A$ of the form contains orders about code status: full code (attempt CPR) or do not resuscitate (DNR). Section B contains orders about the preferred level of medical intervention: comfort measures, limited additional interventions, or full treatment. Section C contains orders about preferences for antibiotics: comfort focused, limited antibiotics or full antibiotic 
treatment. (In some states, antibiotics orders have been incorporated into Section B.) Section D contains orders about preferences for artificial nutrition: none, a defined trial period, or long-term use. A physician signature is required to activate the form, with some states permitting signatures by physician assistants and nurse practitioners. In many states, the patient or their surrogate must also sign the form.[5] It is recommended that the form be reviewed and decisions revisited whenever there is a change in the patient's medical condition.[4]

Research has been part of the POLST program since its initial development in Oregon in the early 1990s. The precursor to POLST was called the Medical Treatment Coversheet (MTC), a form that included orders about resuscitation, emergency services, antibiotics, and artificial fluids and nutrition. Focus groups and hypothetical scenarios were used to assess the acceptability of the MTC and determine whether use changed treatment decisions that physicians and paramedics made as intended.[6] A second study evaluated the use of the MTC in nursing facilities to determine how patients, healthcare providers, and administrators used and perceived it. Significant modifications were made to the form based on these studies, and the resulting form was renamed the POLST.[7]

Since that time, use of the POLST has spread throughout the United States. As of June 2014, 43 states had active or developing programs based on the POLST model.[4] A systematic review of the literature was undertaken to describe and evaluate the available evidence regarding use of the POLST in the clinical setting. A goal of this review was to identify directions for future research on the POLST.

Methods

The OVID Medline database (January 1, 1990-June 30, 2014) was searched for published research studies conducted in the United States focused on use of the POLST program in the clinical setting. Key words searched included "POLST," "MOLST," "physician orders for life-sustaining treatment," "medical orders for life-sustaining treatment," "physician orders for scope of treatment," 
and "medical orders for scope of treatment." The search yielded 59 results. The titles and abstracts of the citations were initially reviewed and narrowed to include only articles and research letters reporting research findings, resulting in a sample of 23 studies. This list was compared with a list of publications maintained by the National POLST Paradigm Task Force (www.POLST.org) and publications known to the authors. Five additional recently published studies were identified. Next, two of the authors (SH and EK) reviewed and discussed each study to ensure that it met the inclusion criteria of research focused on use of POLST in the clinical setting. Five research articles were eliminated because they were not specific to clinical care,[8-12] leaving a sample of 23 data-based research studies focused on the use of POLST in the clinical setting. Each article was reviewed, and information was extracted to address important questions regarding use of the POLST in the clinical setting. For clarity, the form will be referred to as POLST throughout the manuscript, although the name varies according to state.

Findings

Study Characteristics

Twelve of the 23 POLST research studies were conducted fully or in part in Oregon, and 11 focused on the nursing facility setting. Chart review is the most common method of data collection (10/23), and 16 studies report patient data (Table 1). Table 2 contains a summary of research studies focused on the POLST and major findings.

Characteristics of POLST Users

Several studies have found differences in POLST use based on participant characteristics. Advanced age is associated with POLST use,[13-15] and orders to limit resuscitation, medical treatments, $[13,16]$ and artificial nutrition and hydration[16] are more common in older patients. Nonwhite patients use POLST forms less frequently $[17,18]$ and generally have orders for moreaggressive interventions in Section B than white patients.[17] High rates of POLST use are found in the 
records of people who died in hospice (74\%)[19] and in one community sample (67\%),[15] suggesting that use may be common near the end of life. A recent study found that just under one-third of all patients who died from natural causes in 2010 and 2011 had a POLST form in a statewide registry.[18] In that sample, cancer was the most common primary diagnosis noted on the death certificate, followed by heart disease.[18] A nursing facility study found that a majority of POLST forms (76\%) were signed by someone other than the patient (e.g., a legal representative), perhaps because most of the patients in the sample had a diagnosis of dementia.[20] Research in the hospital,[21] hospice setting,[19] and community,[15] suggests that patients are involved in the POLST discussion a majority of the time, even if the form is signed by a surrogate.

Completing the POLST Form

Although the POLST form requires a physician or nurse practitioner signature to activate the form, the POLST conversation is often initiated by a non-physician facilitator who helps prepare the form for the clinician to review and sign. In hospice and nursing facilities, social services or nurses typically prepare the POLST form.[17, 19]

Patterns of POLST Orders

POLST forms are used to document a range of treatment preferences. In a community study of deceased patients, POLST forms were found to contain 35 of 36 possible clinically reasonable combinations. Approximately one-third of patients had orders for the lowest level of treatment in all POLST form sections (e.g., do not resuscitate (DNR), comfort measures, antibiotics for comfort only, and no artificial nutrition),[15] nearly identical to the percentage of patients with POLST form orders for DNR and comfort measures in a statewide registry.[13] Nevertheless, many patients with DNR orders have orders for a higher level of treatment in one or more sections of the form, suggesting that POLST code status orders are not predictive of orders in other sections of the form.[14-16, 19] A minority of POLST 
forms contain orders that conflict or may be confusing to healthcare providers.[13] Table 3 provides an overview of POLST orders for patients according to setting.

Healthcare Provider Attitudes Toward and Experiences with POLST

Healthcare providers report that POLST reliably expresses patients preferences and guides care.[16] Most agree that the form can improve communication and is useful in initiating conversations about patients' end-of-life wishes. Many also feel it has a positive effect on communication between the nursing home and hospital.[22] A majority of hospice personnel[19] and emergency medical technicians[23]report that the POLST is useful in determining treatment when the individual is in cardiopulmonary arrest, preventing unwanted resuscitation, and avoiding unwanted hospitalization. Healthcare providers who work with in facilities where there is a higher prevalence of POLST use better understand the technicalities of the program and are more likely to report positive experiences than those in facilities with lower prevalence.[24]

Healthcare providers also report challenges using the POLST form. Although only a minority of participants in each study reports these concerns, there are similarities in the kinds of challenges identified. These problems include difficulty understanding and explaining the form,[19, 2426] challenges obtaining a clinician signature on forms that other members of the healthcare team prepare,[19, 25, 27]discomfort with problems that the form raises,[19] problems when transferring POLST across settings, $[19,23,25-27]$ family disagreements about the content, $[25,27]$ problems with using POLST to guide treatment,[25] and inadequate education about the form for providers.[19, 25] The time required to complete a POLST can also represent a barrier to use in some settings.[22, 28] In one survey, emergency medical responders were unaware of basic facts about POLST (e.g., that photocopies are valid).[28]

POLST and Its Effect on Treatment Decisions 
Section A: Cardiopulmonary Resuscitation

Section A orders are the only category of treatments where it is possible to identify overtreatment and undertreatment using chart review methods. Studies have found overall high rates of consistency between the withholding of CPR and Section A orders for deceased individuals.[15, 19, 29-32] POLST full code orders are less common at the time of death than POLST DNR orders.[15, 30, 31] In one sample of individuals with POLST forms indicating full code in Section $A$ ( $n=32$ ), EMS attempted resuscitation for $84 \%$ (27/32) of individuals found in cardiac arrest.[32] In another study, participants with full code orders who died $(n=5)$ were transferred to the intensive care unit, but resuscitation was not attempted because the orders were rewritten before death.[15]

Section B: Medical Interventions

Data about the consistency between treatments and Section B orders (e.g., hospitalization) are mixed. Although three studies found no evidence of unwanted ventilator or intensive care unit care and low rates of unwanted hospitalization for participants with orders for comfort measures, $[15,17,19$, 30] it was unclear whether these interventions were indicated and withheld based on the POLST orders for comfort measures or not provided because they were never medically indicated. An early study found that medical interventions were consistent with Section B orders for comfort measures $46 \%$ of the time but did not take into account the rationale for discrepancies.[31] In a multistate study of nursing home residents, high rates of consistency (91\%) were found between POLST Section B orders and treatments when the rationale for discrepancies were considered.[30] Individuals with a POLST form indicating comfort measures in Section B were significantly less likely than those with orders for full treatment in Section B to receive treatments including intravenous fluids, transfer to the emergency department, and admission to the hospital.[15, 17] Individuals with POLST orders for comfort measures were also less likely to die in the hospital than those with POLST orders for full 
treatment.[18] Individuals with POLST orders for full treatment received the same number of medical interventions as those without POLST forms.[17]

Section C: Antibiotics

High rates of consistency have also been found between antibiotic use and Section C orders, [30, 31] particularly when the orders direct the use of antibiotics to enhance comfort. Orders unilaterally prohibiting the use of antibiotics are less common. These orders may not be as useful, either. In one study, orders to withhold antibiotics were violated in $32 \%$ of cases.[30] Orders to limit or provide antibiotics do not appear to alter the frequency of antibiotics use, $[17,33]$ which may be due to the frequency of infections requiring antibiotics to enhance comfort (e.g., urinary tract, skin)[17] as opposed to infections for which comfort needs can be met without antibiotics (e.g., respiratory).[30]

Section D: Artificial Nutrition

The use of artificial nutrition seems to be generally consistent with Section D orders to withhold feeding tubes, although the causality of this relationship is unclear.[15, 30, 31] It is less clear whether orders for a time-limited trial of artificial nutrition are honored.[30]

Symptom Management

An early study found high rates of use of medical orders for opioids in the records of participants with POLST forms, and orders for opioids were significantly higher for participants in the final month of life than for other patients.[29] In a later study chart review comparing patients with and without POLST forms there were no differences in the assessment and management of pain or shortness of breath when variables including life status (living vs deceased) and hospice use were included in the analysis.[17]

Patient Treatment Preferences and POLST 
Chart reviews suggest high rates of documentation of conversations and consent related to POLST form completion.[15, 34] In a 2004 study, 100\% (12/12) of the POLST forms examined matched the preferences documented on the patients' advance directives. In $90 \%$ of cases (19/21), patients' wishes were honored, and interviews with seven patients or their surrogates found that POLST orders were consistent with preferences a majority of the time.[34] In a more-recent study, patients or their legal healthcare agents were interviewed about their recall of discussions regarding treatment decisions,[21] 72\% (23/32) of POLST orders were consistent with recall of decisions about life-sustaining treatments. Six of nine discrepancies were situations in which the participant reported a desire to limit treatments, and the POLST form reflected orders for full treatment.[21] In interviews with patients and surrogates regarding their experiences with use of the POLST form in the emergency setting, $91 \%$ (10/11) reported that treatment preferences were honored.[35]

Discussion

Summary of POLST Research

Existing research suggests that POLST is most often used to guide the care of older adults[13, 14, 16] who are near the end of life. Social service providers or nurses most commonly initiate discussion about the form.[16, 19] Use of the POLST program helps ensure that an individualized care plan is documented in the patient's medical record.[13-16, 19] Code status is not predictive of a patient's preferences for other kinds of treatments, $[14,16,19]$ highlighting the limitations of relying on code status alone to guide treatment decisions.[36]

Healthcare providers largely hold positive views of POLST and find it useful in guiding discussions and decisions about treatments, but there are numerous challenges associated with use of the tool, ranging from challenges understanding and explaining the form[19, 24-26]to logistical challenges such as problems transferring the form across settings.[19, 23, 25-27] Although only a minority of 
respondents identified these problems, the concerns raised suggest the need for systems-focused quality improvement efforts.

The evidence suggests that POLST orders reflecting decisions to withhold interventions are usually honored $[15,17,19,29,30,32]$ and that treatments are largely consistent with orders, particularly for orders in Section A (resuscitation) and Section B (medical interventions).[30]POLST orders for comfort measures in Section B are associated with lower rates of hospitalization[17] and inhospital death.[18] Existing data about whether POLST accurately represents patient preferences is weak because of a reliance on small samples with methodological limitations.[15, 21, 34, 35] There is also minimal information about the effect of POLST use on symptom management[17] and overall quality of life for individuals who elect a comfort-focused plan of care. Given that individuals with orders for comfort measures are more likely to die at home,[18] it is unknown how well comfort needs are being met in this setting.

Limitations of POLST Research

More than half of the studies on POLST have been conducted in Oregon, but it is unclear whether findings from Oregon are readily generalizable to other states. Oregon is a largely white and homogenous state,[37] and there have been intensive and ongoing efforts to implement POLST in Oregon since the early 1990s. A recent review of existing POLST programs suggest that healthcare provider training and education about how to facilitate POLST is uneven and has been identified as the greatest implementation challenge for other states as they adopt POLST.[5]

A significant number of existing POLST studies rely on descriptive data, often gathered from small, nonrandom convenience samples. In these studies, it is difficult to determine how representative the sample is of the overall population, raising questions about the generalizability of findings. Much of the existing research has focused heavily on the nursing facility setting, where POLST use is more 
common, but data about the use of POLST in the community, where skilled nursing and medical care is not as readily accessible to seriously ill or dying patients is limited. Additionally, there has been no research to evaluate whether POLST is used for individuals with advanced chronic progressive disease or frailty as intended or if it is being used in other populations.

\section{Recommendations for Future Research}

Given the strong evidence that POLST alters the kinds of treatments provided in a way that is consistent with documented orders, research designed to evaluate the quality of POLST decisions should be a high priority. Concordance between current preferences and treatment decisions is integral to the provision of patient-centered care.[38, 39] POLST orders should reflect the well-informed, current preferences of patients and undergo periodic review to determine whether there have been any changes in preferences over time. Research on decision quality, decision outcomes such as decision regret, and patient and surrogate experiences with POLST could lead to the development of evidencebased educational and decision-support tools. Improved decision aids may also better enable healthcare providers to more effectively target conversations during typically brief clinic appointments.

Another direction for future research is to assess healthcare provider understanding and application of POLST form concepts (e.g., comfort measures). This information could be used to guide in the development of education materials for healthcare providers and facilitate the identification of practice standards for interpretation of POLST orders. Preliminary guidelines to determine whether interventions are comfort focused or potentially life prolonging have been proposed, but require further research to determine whether these definitions are agreed upon in practice.[30] A related need for future study is an evaluation of healthcare provider educational programs to identify best practices. Additionally, although healthcare providers report challenges associated with POLST use,[19, 22, 24, 25, 27] the extent of these problems and their effect on patients is unknown. It is also unclear whether 
reported concerns are unique to POLST or reflective of broader challenges in advance care planning[40, 41] and informed consent.[42] Research focused on healthcare provider experiences with POLST could help improve education and training about best practices for POLST and advance care planning, inform program changes, and shape policy at the state and federal level.

Finally, prospective intervention trials and epidemiological studies are needed to better understand how POLST does or does not change clinical outcomes and healthcare utilization. Larger prospective intervention trials would permit comparison within and between populations and allow for assessment of variables not typically captured in a standardized manner during clinical care, such as quality of life and overall symptom distress. Electronic medical records and electronic registries hold the potential to serve as links between POLST orders and clinical care. Medicare claims data are one avenue to explore these questions at a population level that would also enable the focus of research to be broadened beyond the long-term care and hospice setting, but this is challenging without specific and regularly updated data regarding individuals' POLST form orders. Alternatively, use of POLST could be integrated into national data sets such as the Minimum Data Set to track use, a change that has already occurred in California.[43] This approach would also permit linkages to vital statistics, claims data, and other relevant information to understand the full effect of the program and identify areas for improvement in states with different practice cultures and diverse populations. This approach would also permit the analysis of cost with sufficient information to control for potential confounders. Finally, such data could help identify how and why decisions and treatments change over time.

Conclusions

POLST is a geriatric palliative care tool that is widely used to document a range of treatment preferences. Use of the form alters clinical care in a way that is consistent with POLST orders, but there are limitations with the existing research that merit further investigation. Directions for future research 
include focusing on evaluating the quality of POLST decision-making, exploring the experiences of patients and their surrogates, identifying gaps in clinical education, the development of decision-support tools, intervention studies, and epidemiologic analysis of the effect of POLST on care outcomes.

\section{Acknowledgements}

Conflict of Interest: Dr. Hickman is the Co-Chair of the Indiana Patient Preferences Coalition, which supported passage of the Indiana Physician Orders for Scope of Treatment law. She has received honoraria for speaking about POLST research and consulted with other researchers on POLST research and implementation. Dr. Hammes is a former member of the National POLST Paradigm Task Force Executive Board. He has received honoraria for speaking about POLST research and consulted with other researchers on POLST research and implementation. Dr. Hammes is Director of the Respecting Choices $^{\bullet}$ program, which provides facilitator training that helps prepare health professionals to have discussions with patients so they can complete the POLST form.

Author Contributions: Hickman: overall literature review including overall concept, identifying of studies, summary of findings, preparation of manuscript. Keevern: identification of studies, summary of findings, preparation of manuscript. Hammes: preparation of manuscript.

Sponsor's Role: None. 
References

1 A National Framework and Preferred Practices for Palliative and Hospice Care Quality: A Consensus Report. Washington, DC: National Quality, Forum, 2006.

2 Hickman SE, Hammes BJ, Moss AH et al. Hope for the future: Achieving the original intent of advance directives. Hastings Cent Rep 2005;Spec No:S26-S30.

3 Center to Advance Palliative Care. Improving Palliative Care in Nursing Homes, 2007 [on-line]. Available at http://www.capc.org/palliative-care-across-the-continuum/longterm/ Accessed January 27, 2014.

4 The National POLST Paradigm Program, 2012 [on-line]. Available at www.polst.org Accessed March 23, 2014.

5 Sabatino C, Karp N. Improving Advanced Illness Care: The Evolution of State POLST Programs, 2011 [on-line]. Available at http://www.aarp.org/health/doctors-hospitals/info-04-2011/polst-04-11.html Accessed November 13, 2014.

6 Dunn PM, Schmidt TA, Carley MM et al. A method to communicate patient preferences about medically indicated life-sustaining treatment in the out-of-hospital setting. J Am Geriatr Soc 1996;44:785-791.

7 Dunn P, Nelson CA, Tolle SW et al. Communicating preferences for life-sustaining treatment using a physician order form. J Gen Intern Med 1997;12(Suppl):102.

8 Resnick HE, Foster GL, Hickman SE. Nursing home participation in end-of-life programs: United States, 2004. Am J Hospice Palliat Med 2009;26:354-360. 
9 Olszewski EA, Newgard CD, Zive D et al. Validation of Physician Orders for Life-Sustaining Treatment: Electronic registry to guide emergency care. J Am Geriatr Soc 2012;60:1384-1386.

10 Hickman SE, Sabatino CP, Moss AH et al. The POLST (Physician Orders for Life-Sustaining Treatment) paradigm to improve end-of-life care: Potential state legal barriers to implementation. J Law Med Ethics 2008;36:119-140, 144.

11 Matthews JJ, Souther CE. Factors associated with implementation of the POLST paradigm: Results from a survey of Florida physicians. Care Manag J 2013;14:247-253.

12 Wilson CJ, Newman J, Tapper S et al. Multiple locations of advance care planning documentation in an electronic health record: Are they easy to find? J Palliat Med 2013;16:1089-1094.

13 Schmidt TA, Zive D, Fromme EK et al. Physician Orders for Life-Sustaining Treatment (POLST): Lessons learned from analysis of the Oregon POLST Registry. Resuscitation 2014;85:480-485.

14 Fromme EK, Zive D, Schmidt TA et al. POLST Registry do-not-resuscitate orders and other patient treatment preferences. JAMA 2012;307:34-35.

15 Hammes BJ, Rooney BL, Gundrum JD et al. The POLST program: A retrospective review of the demographics of use and outcomes in one community where advance directives are prevalent. J Palliat Med 2012;15:77-85.

16 Hickman SE, Tolle SW, Brummel-Smith K et al. Use of the Physician Orders for Life-Sustaining Treatment program in Oregon nursing facilities: Beyond resuscitation status. J Am Geriatr Soc 2004;52:1424-1429.

17 Hickman SE, Nelson CA, Perrin NA et al. A comparison of methods to communicate treatment preferences in nursing facilities: Traditional practices versus the Physician Orders for Life-Sustaining Treatment program. J Am Geriatr Soc 2010;58:1241-1248. 
18 Fromme EK, Zive D, Schmidt TA et al. Association between Physician Orders for Life-Sustaining Treatment for scope of treatment and in-hospital death in Oregon. J Am Geriatr Soc 2014;62:12461251.

19 Hickman SE, Nelson CA, Moss AH et al. Use of the Physician Orders for Life-Sustaining Treatment (POLST) paradigm program in the hospice setting. J Palliat Med 2009;12:133-141.

20 Araw AC, Araw AM, Pekmezarius R et al. Medical orders for life-sustaining treatment: Is it time yet? Palliat Support Care 2014;12:101-105.

21 Hickman SE, Nelson CA, Smith-Howell E et al. Use of the Physician Orders for Life-Sustaining Treatment program for patients being discharged from the hospital to the nursing facility. J Palliat Med 2014;17:43-49.

22 Caprio AJ, Rollins VP, Roberts E. Health care professionals' perceptions and use of the Medical Orders for Scope of Treatment (MOST) form in North Carolina nursing homes. J Am Med Dir Assoc 2012;13:162-168.

23 Schmidt TA, Hickman SE, Tolle SW et al. The Physician Orders for Life-Sustaining Treatment program: Oregon emergency medical technicians' practical experiences and attitudes. J Am Geriatr Soc 2004;52:1430-1434.

$24 \mathrm{Vo} \mathrm{H}$, Pekmezaris R, Guzik H et al. Knowledge and attitudes of health care workers regarding MOLST (Medical Orders for Life-Sustaining Treatment) implementation in long-term care facilities. Geriatr Nurs 2011;32:58-62.

25 Sugiyama T, Zingmond D, Lorenz KA et al. Implementing Physician Orders for Life-Sustaining Treatment in California hospitals: Factors associated with adoption. J Am Geriatr Soc 2013;61:13371344. 
26 Waldrop DP, Clemency B, Maguin E et al. Preparation for frontline end-of-life care: Exploring the perspectives of paramedics and emergency medical technicians. J Palliat Med 2014;17:338-341.

27 Wenger NS, Citko J, O'Malley K et al. Implementation of Physician Orders for Life Sustaining Treatment in nursing homes in California: Evaluation of a novel statewide dissemination mechanism. J Gen Intern Med 2013;28:51-57.

28 Sam S, Pekmezaris R, Nouryan CN et al. Survey of emergency medical services professionals' experience with advance directives and medical orders for life-sustaining treatment. J Am Geriatr Soc 2011;59:2383-2384.

29 Tolle SW, Tilden VP, Nelson CA et al. A prospective study of the efficacy of the Physician Orders for Life-Sustaining Treatment. J Am Geriatr Soc 1998;46:1097-1102.

30 Hickman SE, Nelson CA, Moss AH et al. The consistency between treatments provided to nursing facility residents and orders on the Physician Orders for Life-Sustaining Treatment form. J Am Geriatr Soc 2011;59:2091-2099.

31 Lee MA, Brummel-Smith K, Meyer J et al. Physician Orders for Life-Sustaining Treatment (POLST): Outcomes in a PACE program. Program of All-Inclusive Care for the Elderly. J Am Geriatr Soc 2000;48:1219-1225.

32 Richardson DK, Fromme E, Zive D et al. Concordance of out-of-hospital and emergency department cardiac arrest resuscitation with documented end of-life choices in Oregon. Ann Emerg Med 2014;63:375-383.

33 Dolan EC, Ovian DR, Hammes BJ et al. Effect of Physician Orders for Life-Sustaining Treatment documents on antimicrobial use and antimicrobial-resistant organism infections in nursing home residents. Clin Infect Dis 2014;58:1339-1340. 
34 Meyers JL, Moore C, McGrory A et al. Orders for Life-Sustaining Treatment form: Honoring end-of-life directives for nursing home residents. J Gerontol Nurs 2004;30:37-46.

35 Schmidt TA, Olszewski EA, Zive D et al. The Oregon Physician Orders for Life-Sustaining Treatment registry: A preliminary study of emergency medical services utilization. J Emerg Med 2013;44:796-805.

36 Happ MB, Capezuti E, Strumpf NE et al. Advance care planning and end-of-life care for hospitalized nursing home residents. J Am Geriatr Soc 2002;50:829-835.

37 State of Oregon. Oregon's Demographic Trends, 2011 [on-line]. Available at www.oregon.gov/DAS/../demographic/or_pop_trend2011.pdf Accessed March 21, 2014.

38 Sepucha K, Ozanne EM. How to define and measure concordance between patients' preferences and medical treatments: A systematic review of approaches and recommendations for standardization. Patient Educ Couns 2010;78:12-23.

39 Institute of Medicine. Crossing the Quality Chasm: A New Health System for the 21st Century, 2001 [on-line]. Available at http://www.iom.edu/ /media/Files/Report\%20Files/2001/Crossing-the-QualityChasm/Quality\%20Chasm\%202001\%20\%20report\%20brief.pdf Accessed January 29, 2014.

40 Heyland DK, Barwich D, Pichora D et al. Failure to engage hospitalized elderly patients and their families in advance care planning. JAMA Intern Med 2013;173:778-787.

41 Fagerlin A, Schneider CE. Enough. The failure of the living will. Hastings Cent Rep 2004;34:30-42.

42 Lavelle-Jones C, Byrne DJ, Rice P et al. Factors affecting quality of informed consent. BMJ 1993;306:885-890. 
43 California Department of Public Health. Information for Health Care Providers-Minimum Data Set (MDS 3.0): MDS 3.0 CA Section S.. Available at http://www.cdph.ca.gov/programs/LnC/Pages/MDS.aspx Accessed December 2, 2014. 
Table 1. Characteristics of Physician Orders for Life-Sustaining Treatment Research Studies $(n=23)$ (January 1998-June 2014)

\begin{tabular}{|c|c|}
\hline Characteristic & $\mathrm{N}$ \\
\hline \multicolumn{2}{|l|}{ State } \\
\hline Oregon & 9 \\
\hline Wisconsin & 2 \\
\hline New York & 4 \\
\hline California & 3 \\
\hline North Carolina & 1 \\
\hline Washington & 1 \\
\hline Multistate (Oregon, Wisconsin, West Virginia) & 3 \\
\hline \multicolumn{2}{|l|}{ Methods } \\
\hline Chart review & 10 \\
\hline Chart review and interview & 3 \\
\hline Chart review and survey & 2 \\
\hline Survey & 6 \\
\hline Survey and interview & 2 \\
\hline \multicolumn{2}{|l|}{ Clinical setting } \\
\hline Nursing facility & 11 \\
\hline Hospital & 1 \\
\hline Community (mixed) & 5 \\
\hline Emergency medical services & 5 \\
\hline Hospice & 1 \\
\hline \multicolumn{2}{|l|}{ Study population } \\
\hline Patients and family members & 16 \\
\hline Healthcare providers & 7 \\
\hline
\end{tabular}

Two studies are counted separately in this list but are based on the same sample.[17, 30] 
Table 2. An Overview of Research on Physician Orders for Life-Sustaining Treatment (POLST) and Important Findings

\begin{tabular}{|c|c|c|c|c|c|c|}
\hline Reference & State & Method & $\begin{array}{l}\text { Primary } \\
\text { Setting }\end{array}$ & $\begin{array}{l}\text { Sample } \\
\text { Size, N }\end{array}$ & Study Population & Summary of Major Findings \\
\hline $\begin{array}{l}\text { Tolle et al., } \\
\text { 1998[29] }\end{array}$ & OR & $\begin{array}{l}\text { Chart } \\
\text { review and } \\
\text { interview }\end{array}$ & $\begin{array}{l}\text { Nursing } \\
\text { facilities }\end{array}$ & 180 & $\begin{array}{l}\text { Patients with } \\
\text { POLST forms } \\
\text { marked DNR and } \\
\text { comfort } \\
\text { measurses }\end{array}$ & $\begin{array}{l}\text { High rates of comfort measures } \\
\text { consistent with orders on POLST. Only } \\
13 \% \text { of patients were hospitalized } \\
\text { during study, and most ( } 85 \% \text { ) were } \\
85 \% \text { for comfort. Almost all ( } 95 \% \text { ) of } \\
\text { patients who died during the study } \\
\text { died in } \mathrm{NH} \text {, as preferred. }\end{array}$ \\
\hline $\begin{array}{l}\text { Lee et al., } \\
2000[31]\end{array}$ & OR & $\begin{array}{l}\text { Chart } \\
\text { review }\end{array}$ & Community & 54 & $\begin{array}{l}\text { Deceased } \\
\text { patients with } \\
\text { POLST forms } \\
\text { enrolled in } \\
\text { Program of All } \\
\text { Inclusive Care }\end{array}$ & $\begin{array}{l}\text { CPR use consistent with orders on } \\
\text { POLST ( } 91 \%) \text {. High levels of } \\
\text { consistency in use of CPR, antibiotics, } \\
\text { intravenous fluids, and feeding tubes. } \\
\text { About half ( } 45 \% \text { ) of interventions } \\
\text { provided were consistent with the } \\
\text { level indicated on POLST Section B. }\end{array}$ \\
\hline $\begin{array}{l}\text { Meyers } \\
\text { et al., } \\
2004[34]\end{array}$ & WA & $\begin{array}{l}\text { Chart } \\
\text { review and } \\
\text { interview }\end{array}$ & $\begin{array}{l}\text { Nursing } \\
\text { facilities }\end{array}$ & 21 & $\begin{array}{l}\text { Patients with } \\
\text { POLST forms }\end{array}$ & $\begin{array}{l}\text { POLST accurately reflected wishes in } \\
19 \text { of } 21(90 \%) \text { cases. Documentation } \\
\text { of consent found in } 16 \text { of } 21 \text { ( } 76 \%) \\
\text { cases. }\end{array}$ \\
\hline
\end{tabular}




\begin{tabular}{|c|c|c|c|c|c|c|}
\hline $\begin{array}{l}\text { Hickman } \\
\text { et al., } \\
2004[16]\end{array}$ & OR & $\begin{array}{l}\text { Telephone } \\
\text { survey } \\
\text { Chart } \\
\text { review }\end{array}$ & $\begin{array}{l}\text { Nursing } \\
\text { facilities }\end{array}$ & $\begin{array}{l}146 \\
355\end{array}$ & $\begin{array}{l}\text { Staff at nursing } \\
\text { facilities } \\
\text { Living and } \\
\text { deceased } \\
\text { Patients aged } \geq 65 \\
\text { with POLST forms }\end{array}$ & $\begin{array}{l}71 \% \text { facilities used POLST for at least } \\
\text { half of patients; } 88 \% \text { of POLST forms } \\
\text { were marked DNR, } 77 \% \text { of which } \\
\text { reflected orders for more than lowest } \\
\text { level of treatment in at least one } \\
\text { other area. }\end{array}$ \\
\hline $\begin{array}{l}\text { Schmidt } \\
\text { et al., } \\
2004[23]\end{array}$ & $\mathrm{OR}$ & $\begin{array}{l}\text { Survey, } \\
\text { scenarios }\end{array}$ & EMS & 572 & EMTs & $\begin{array}{l}73 \% \text { of EMTs surveyed had treated a } \\
\text { patient with a POLST and the orders } \\
\text { changed treatment decisions in } 45 \% \\
\text { of cases. } 75 \% \text { agreed that the form } \\
\text { provides clear instructions regarding } \\
\text { preferences and } 93 \% \text { that it is useful } \\
\text { for determining treatment for } \\
\text { individuals in cardiopulmonary arrest. }\end{array}$ \\
\hline $\begin{array}{l}\text { Hickman } \\
\text { et al., } \\
2009[19]\end{array}$ & $\begin{array}{l}\text { OR, } \\
\text { WI, } \\
\text { WV }\end{array}$ & $\begin{array}{l}\text { Telephone } \\
\text { survey } \\
\text { Chart } \\
\text { review }\end{array}$ & Hospice & $\begin{array}{l}133 \\
256\end{array}$ & $\begin{array}{l}\text { Staff at hospice } \\
\text { facilities. } \\
\text { Hospice patients } \\
\text { with POLST forms } \\
\text { who had died in } \\
\text { last } 12 \text { months }\end{array}$ & $\begin{array}{l}97 \% \text { of staff believed POLST useful in } \\
\text { preventing unwanted resuscitation } \\
\text { and } 96 \% \text { in initiating conversations } \\
\text { regarding treatment preferences; } 99 \% \\
\text { of patients had DNR orders, and } 78 \% \\
\text { had orders for more than lowest level } \\
\text { of intervention in at least one other } \\
\text { category. Preferences indicated on } \\
\text { POLST respected in } 98 \% \text { of cases and } \\
\text { no one received unwanted CPR. }\end{array}$ \\
\hline $\begin{array}{l}\text { Hickman } \\
\text { et al., } \\
\text { 2010[17] }\end{array}$ & $\begin{array}{l}\text { OR, } \\
\text { WI, } \\
\text { WV }\end{array}$ & $\begin{array}{l}\text { Chart } \\
\text { review }\end{array}$ & $\begin{array}{l}\text { Nursing } \\
\text { facilities }\end{array}$ & 1,711 & $\begin{array}{l}\text { Living and } \\
\text { deceased } \\
\text { patients aged } \geq 65\end{array}$ & $\begin{array}{l}\text { Patients with POLSTs more likely to } \\
\text { have preferences indicated beyond } \\
\text { CPR status (98\%) than those without } \\
(16 \%) \text {. Patients with POLST orders for }\end{array}$ \\
\hline
\end{tabular}


with minimum

60-day stay comfort measures only were less likely to receive interventions such as hospitalization than those with full treatment orders or with traditional advance directives. Participants who were white, in hospice, and deceased more frequently had POLST forms in charts.

\begin{tabular}{|c|c|c|c|c|c|c|}
\hline $\begin{array}{l}\text { Hickman } \\
\text { et al., } \\
2011[30]\end{array}$ & $\begin{array}{l}\text { OR, } \\
\text { WI, } \\
\text { WV }\end{array}$ & $\begin{array}{l}\text { Chart } \\
\text { review }\end{array}$ & $\begin{array}{l}\text { Nursing } \\
\text { facilities }\end{array}$ & 870 & $\begin{array}{l}\text { Living and } \\
\text { deceased } \\
\text { patients aged } \geq \\
65 \text { with POLST } \\
\text { forms and } \\
\text { minimum 60-day } \\
\text { stay }\end{array}$ & $\begin{array}{l}\text { High consistency between orders } \\
\text { indicated on POLST and treatment } \\
\text { provided in areas of resuscitation } \\
(98 \%) \text {, medical interventions ( } 91 \%) \\
\text { and antibiotics (93\%). Consistency } \\
\text { with feeding tube orders was } 64 \% \text {. } \\
\text { Treatment received was highly } \\
\text { consistent with orders on POLST } \\
(94 \%) \text {. }\end{array}$ \\
\hline
\end{tabular}

$\begin{array}{lll}\text { Vo et al., } & \text { NY Survey } & \text { Nursing } \\ \text { 2011[24] } & & \end{array}$
Nurses,

physicians, patients, fellows, social workers,

nurse

practitioners
Staff felt physicians were ultimately responsible for discussing POLST. 47\% of staff where POLST use is more prevalent felt patients with POLST forms had better pain management, versus $12 \%$ of staff at facilities with low prevalence of POLST use. Staff at facilities with high prevalence of POLST use tended to be more knowledgeable regarding form details and completion. 


\begin{tabular}{|c|c|c|c|c|c|c|}
\hline $\begin{array}{l}\text { Sam et al., } \\
2011[28]\end{array}$ & NY & Survey & EMS & 230 & EMRs & $\begin{array}{l}68 \% \text { of EMRs surveyed were } \\
\text { comfortable honoring POLST, } \\
\text { although those with more experience } \\
\text { reported greater comfort than those } \\
\text { with less experience. Many were } \\
\text { unaware that a copy is valid ( } 72 \%) \\
\text { and that the original is pink ( } 54 \%) \text {. } \\
\text { Half ( } 52 \% \text { )received training on POLST } \\
\text { but only } 29 \% \text { had ever been } \\
\text { presented with a POLST in the field. }\end{array}$ \\
\hline $\begin{array}{l}\text { Hammes } \\
\text { et al., } \\
2012[15]\end{array}$ & WI & $\begin{array}{l}\text { Chart } \\
\text { review }\end{array}$ & $\begin{array}{l}\text { Community } \\
\text { (La Crosse } \\
\text { County) }\end{array}$ & 400 & $\begin{array}{l}\text { Medical records } \\
\text { and death } \\
\text { certificates of } \\
400 \text { patients who } \\
\text { died in 7-month } \\
\text { period }\end{array}$ & $\begin{array}{l}67 \% \text { of patients had POLST forms on } \\
\text { file at the time of death and } 22 \% \text { had } \\
\text { only a POAHC. Those with POLST were } \\
\text { older than those with a POAHC and } \\
\text { more likely to die in a nursing home } \\
\text { from a chronic or terminal illness. } \\
\text { Treatment provided to patients with } \\
\text { POLST forms was consistent with } \\
\text { orders for higher levels of treatment. }\end{array}$ \\
\hline $\begin{array}{l}\text { Caprio } \\
\text { et al., } \\
2012[22]\end{array}$ & NC & $\begin{array}{l}\text { Survey and } \\
\text { interview }\end{array}$ & $\begin{array}{l}\text { Nursing } \\
\text { facilities }\end{array}$ & 11 & $\begin{array}{l}\text { Physicians, nurse } \\
\text { practitioners, } \\
\text { social workers } \\
\text { from } 2 \text { nursing } \\
\text { homes }\end{array}$ & $\begin{array}{l}10 \text { of } 11 \text { of staff surveyed were able } \\
\text { to explain and interpret POLST form } \\
\text { and agreed that the form improved } \\
\text { communication between physicians, } \\
\text { patients, and families and between } \\
\text { nursing facilities and hospitals. } 36 \% \text { of } \\
\text { staff identified time as a barrier to use } \\
\text { of POLST form. }\end{array}$ \\
\hline
\end{tabular}




\begin{tabular}{|c|c|c|c|c|c|c|}
\hline $\begin{array}{l}\text { Fromme } \\
\text { et al., } \\
2012[14]\end{array}$ & OR & $\begin{array}{l}\text { Chart } \\
\text { review }\end{array}$ & $\begin{array}{l}\text { Community } \\
\text { sample }\end{array}$ & 25,142 & $\begin{array}{l}\text { Patients with } \\
\text { POLST forms in } \\
\text { an electronic } \\
\text { statewide } \\
\text { registry }\end{array}$ & $\begin{array}{l}\text { A majority ( } 86 \%) \text { of patients with } \\
\text { POLST forms in Oregon registry were } \\
\text { aged } 65 \text { or older; } 61 \% \text { were female. } \\
\text { Half of patients with DNR orders had } \\
\text { orders for comfort measures, and half } \\
\text { had orders for limited additional } \\
\text { interventions or full treatment. }\end{array}$ \\
\hline $\begin{array}{l}\text { Wenger } \\
\text { et al., } \\
2012[27]\end{array}$ & $C A$ & Survey & $\begin{array}{l}\text { Nursing } \\
\text { facilities }\end{array}$ & 284 & $\begin{array}{l}\text { Nursing facility } \\
\text { staff }\end{array}$ & $\begin{array}{l}\text { A random sample of nursing facilities } \\
\text { was surveyed. } 82 \% \text { of staff had } \\
\text { received education about POLST, and } \\
59 \% \text { had a formal policy regarding use } \\
\text { of POLST. Facilities reported } \\
\text { challenges with implementation, } \\
\text { including difficulties obtaining } \\
\text { physician signatures. }\end{array}$ \\
\hline $\begin{array}{l}\text { Sugiyama } \\
\text { et al., } \\
2013[25]\end{array}$ & $C A$ & Survey & Hospitals & 286 & $\begin{array}{l}\text { Hospital palliative } \\
\text { care or case } \\
\text { management } \\
\text { personnel }\end{array}$ & $\begin{array}{l}65 \% \text { of hospitals had a policy about } \\
\text { POLST, } 84 \% \text { had educated staff, and } \\
94 \% \text { had experience following POLST } \\
\text { as intended in the emergency } \\
\text { department setting. Hospitals } \\
\text { reported challenges with } \\
\text { implementation, including difficulties } \\
\text { completing the POLST form. }\end{array}$ \\
\hline $\begin{array}{l}\text { Schmidt } \\
\text { et al., } \\
2013[35]\end{array}$ & OR & $\begin{array}{l}\text { Survey } \\
\text { Interview }\end{array}$ & EMS & $\begin{array}{l}23 \\
11\end{array}$ & $\begin{array}{l}\text { EMRs } \\
\text { Patients and } \\
\text { family members }\end{array}$ & $\begin{array}{l}\text { Follow-up interviews were conducted } \\
\text { after EMRs contacted the registry to } \\
\text { access the POLST. Orders changed } \\
\text { treatment in } 44 \% \text { of cases and } \\
\text { affected decisions about transport in }\end{array}$ \\
\hline
\end{tabular}




\begin{tabular}{|c|c|c|c|c|c|c|}
\hline $\begin{array}{l}\text { Hickman } \\
\text { et al., } \\
2014[21]\end{array}$ & WI & $\begin{array}{l}\text { Chart } \\
\text { review } \\
\text { Interview }\end{array}$ & $\begin{array}{l}\text { Hospital and } \\
\text { nursing } \\
\text { facility }\end{array}$ & 176 & $\begin{array}{l}\text { Patients } \\
\text { discharged from } \\
\text { the hospital to } \\
\text { nursing facility } \\
\text { Subset of } \\
\text { patients and } \\
\text { family members }\end{array}$ & $\begin{array}{l}\text { About a third (39\%) of POLST forms } \\
\text { generated in the hospital documented } \\
\text { code status orders only. } 72 \% \text { of POLST } \\
\text { forms were consistent with reports of } \\
\text { prior decisions by nursing facility } \\
\text { residents and family members. }\end{array}$ \\
\hline $\begin{array}{l}\text { Schmidt } \\
\text { et al., } \\
2014[13]\end{array}$ & OR & $\begin{array}{l}\text { Chart } \\
\text { review }\end{array}$ & $\begin{array}{l}\text { Community } \\
\text { sample }\end{array}$ & 31,294 & $\begin{array}{l}\text { Patients with } \\
\text { POLST forms in } \\
\text { an electronic } \\
\text { statewide } \\
\text { registry }\end{array}$ & $\begin{array}{l}\text { Patients with POLST forms were an } \\
\text { average age of } 76.7 \text { (range 0-106); } \\
68 \% \text { had DNR orders. The most } \\
\text { common combination of orders was } \\
\text { DNR/comfort measures ( } 34 \% \text { ) and } \\
\text { DNR/limited interventions ( } 30 \%) .10 \% \\
\text { of forms contained potentially } \\
\text { confusing order combinations. }\end{array}$ \\
\hline $\begin{array}{l}\text { Richardson } \\
\text { et al., } \\
2014[32]\end{array}$ & OR & $\begin{array}{l}\text { Chart } \\
\text { review }\end{array}$ & EMS & 1,577 & $\begin{array}{l}\text { Patients found by } \\
\text { EMS in out-of- } \\
\text { hospital cardiac } \\
\text { arrest }\end{array}$ & $\begin{array}{l}5 \% \text { of individuals who experienced } \\
\text { out-of-hospital cardiac arrest in a 5- } \\
\text { county region had POLST forms in the } \\
\text { electronic Oregon POLST registry. } \\
\text { POLST DNR orders were honored in } \\
78 \%(39 / 50) \text { of cardiac arrests and } \\
\text { POLST full code orders were honored } \\
\text { in } 84 \%(27 / 32) \text { of cardiac arrests. }\end{array}$ \\
\hline
\end{tabular}

$26 \%$ of cases. Most family members reported that treatment matched patient preferences. 


\begin{tabular}{|c|c|c|c|c|c|}
\hline $\begin{array}{l}\text { Araw et al., } \\
2014[20]\end{array}$ & NY & Chart & Nursir & 18 & $\begin{array}{l}\text { Patients with } \\
\text { POLST forms }\end{array}$ \\
\hline
\end{tabular}

$\begin{array}{llllll}\text { Waldrop } & \text { NY } & \text { Survey } & \text { EMS } & 178 & \text { EMRs } \\ \text { et al., } & & & & \\ \text { 2014[26] } & & & & \end{array}$

$\begin{array}{llll}\begin{array}{l}\text { Fromme } \\ \text { et al., }\end{array} & \text { OR } & \begin{array}{l}\text { Chart } \\ \text { review }\end{array} & \begin{array}{l}\text { Community } \\ \text { sample }\end{array}\end{array}$

2014[18]

$\begin{array}{llll}\begin{array}{l}\text { Dolan et al., } \\ \text { 2014[33] }\end{array} & \begin{array}{l}\text { Chart } \\ \text { review }\end{array} & \begin{array}{l}\text { Nursing } \\ \text { facility }\end{array}\end{array}$

\section{8,000}

\section{Deceased}

patients with and without POLST

forms

\section{4}

POLST forms were completed a median of 48 days after admission, though a minority (3\%) were signed the day the patient died. Only $24 \%$ of forms were signed by the patient; most patients $(60 \%)$ had dementia as their primary diagnosis.

$87 \%$ of EMRs reported confidence in interpreting POLST. Education about POLST was formal (72\%), experiential (67\%), and self-directed (25\%). In open-ended questions, EMRs reported that physicians do not explain POLST well to others and it is often hard to locate it when needed.

Less than a third $(31 \%)$ of all patients who died had a POLST form in a statewide POLST registry. Of those with orders for comfort measures in Section B, significantly fewer died in the hospital or emergency department $(6 \%)$ than of decedents with orders for full treatment (44\%).

Patients with orders to use antibiotics for comfort only $(n=22)$ were compared with those with orders for full treatment with antibiotics $(n=22)$. Urinary tract infections were 
the most common infection

documented. There were no

differences in the days of

antimicrobial therapy per 1,000

patient-days between the two groups.

$\mathrm{CPR}=$ cardiopulmonary resuscitation $; \mathrm{DNR}=$ do not resuscitate; $\mathrm{EMT}=$ emergency medical technician; $\mathrm{EMR}=$ emergency medical responder; EMS = emergency medical services; $\mathrm{POAHC}=$ power of attorney for health care. 
Table 3. Orders Documented on Physician Orders for Life-Sustaining Treatment (POLST) Forms by Study

\begin{tabular}{|c|c|c|c|c|c|c|c|c|}
\hline \multirow[t]{2}{*}{ Study } & \multicolumn{2}{|l|}{$\begin{array}{l}\text { Section A: } \\
\text { Resuscitation }\end{array}$} & \multicolumn{2}{|c|}{$\begin{array}{l}\text { Section B: Medical } \\
\text { Interventions }\end{array}$} & \multicolumn{2}{|c|}{$\begin{array}{l}\text { Section C: } \\
\text { Antibiotics }\end{array}$} & \multicolumn{2}{|c|}{$\begin{array}{l}\text { Section D: Artificial } \\
\text { Nutrition }\end{array}$} \\
\hline & $\begin{array}{l}\text { Do Not } \\
\text { Resuscitate }\end{array}$ & Full & $\begin{array}{l}\text { Comfort } \\
\text { Measures }\end{array}$ & $\begin{array}{l}\text { Limited } \\
\text { or Full }\end{array}$ & $\begin{array}{l}\text { None or } \\
\text { Limited }\end{array}$ & Full & None & $\begin{array}{l}\text { Limited } \\
\text { or Full }\end{array}$ \\
\hline $\begin{array}{l}\text { Multistate hospice, } \\
n=256[19]\end{array}$ & 253 (99) & $3(1)$ & $201(79)$ & $54(21)$ & $139(56)$ & $\begin{array}{l}109 \\
(44)\end{array}$ & $\begin{array}{l}217 \\
(88)\end{array}$ & $29(12)$ \\
\hline $\begin{array}{l}\text { Wisconsin community, } \\
n=255[15]\end{array}$ & $250(98)$ & $5(2)$ & $157(62)$ & $89(35)$ & $146(57)$ & $80(31)$ & $\begin{array}{l}148 \\
(58)\end{array}$ & $59(24)$ \\
\hline $\begin{array}{l}\text { Oregon Program of All } \\
\text { Inclusive Care for the } \\
\text { Elderly, } n=54[31]\end{array}$ & $50(93)$ & $4(7)$ & $13(24)$ & $41(76)$ & $5(9)$ & $49(91)$ & $20(37)$ & $30(56)$ \\
\hline $\begin{array}{l}\text { Oregon nursing } \\
\text { facilities, } n=355[16]\end{array}$ & $313(88)$ & $\begin{array}{l}42 \\
(12)\end{array}$ & $142(40)$ & $210(60)$ & $149(42)$ & $\begin{array}{l}206 \\
(58)\end{array}$ & $\begin{array}{l}176 \\
(50)\end{array}$ & $176(50)$ \\
\hline $\begin{array}{l}\text { New York nursing } \\
\text { facilities, } n=161[20]\end{array}$ & $134(83)$ & $\begin{array}{l}27 \\
(17)\end{array}$ & $48(30)$ & $113(70)$ & - & - & $55(34)$ & $106(66)$ \\
\hline $\begin{array}{l}\text { Multistate nursing } \\
\text { facility, } n=741[17]\end{array}$ & $635(86)$ & $\begin{array}{l}106 \\
(14)\end{array}$ & $300(42)$ & $418(58)$ & $255(36)$ & $\begin{array}{l}454 \\
(64)\end{array}$ & $\begin{array}{l}417 \\
(62)\end{array}$ & $261(38)$ \\
\hline $\begin{array}{l}\text { Oregon electronic } \\
\text { registry, } n=25,142[14]\end{array}$ & $18,116(72)$ & $\begin{array}{l}7,026 \\
(28)\end{array}$ & 9,114 (37) & $\begin{array}{l}15,783 \\
(63)\end{array}$ & $\begin{array}{l}13,038 \\
(53)\end{array}$ & $\begin{array}{l}11,740 \\
(47)\end{array}$ & $\begin{array}{l}14,279 \\
(58)\end{array}$ & $\begin{array}{l}10,167 \\
(42)\end{array}$ \\
\hline
\end{tabular}




\begin{tabular}{|c|c|c|c|c|c|c|c|}
\hline $\begin{array}{l}\text { Wisconsin hospital } \\
\text { discharge to nursing }\end{array}$ & $94(53)$ & $\begin{array}{l}82 \\
(47)\end{array}$ & $17(16)$ & $89(84)$ & $24(24)$ & $74(76)$ & $32(37)$ \\
\hline
\end{tabular}

Numbers in parentheses are percentages. Some patients' forms indicated no preference in Sections B, C, and D, so the sample size for each section varies.

${ }^{a}$ Orders to limit antibiotics include the following three types of limitations: antibiotics for comfort measures only, no intramuscular or intravenous antibiotics, and determine use at time of infection. The New York version of POLST does not contain separate orders for antibiotics. 